\title{
Pengembangan Media Pembelajaran Interaktif Menggunakan Powerpoint- Geogebra Materi Bangun Ruang Sisi Datar Kelas VIII SMP/MTs
}

\author{
Dewi Muliyana ${ }^{1}$, Yenita Roza ${ }^{2}$, Armis $^{3}$ \\ 1,2,3 Program Studi Pendidikan Matematika, Fakultas Keguruan dan Ilmu Pendidikan, Universitas Riau, \\ Kampus Bina Widya Km 12.5, Simpang Baru, Pekanbaru \\ dewi.mulyana2572@student.unri.ac.id
}

\begin{abstract}
This study aims to produce interactive learning media using powerpoint-geogebra valid 2-dimension geometrical material. The research model used in this study is the ADDIE model. The ADDIE development model consists of five stages, namely Analyze, Design, Development, Implement, and Evaluation. Data collection techniques in this study used validation sheets and student response questionnaires. Product validity was assessed based on the results of the validation of material experts and media experts. The practicality of the product was assessed based on the results of small group trials on 6 class VIII students of SMP Negeri 1 Reteh Pulau Kijang. The instruments used in this study were validation sheets of media experts and material experts as well as student response questionnaires. The method used in data collection is by conducting observations and interviews. The data analysis technique in this study consisted of analysis of validation sheets by experts and the audience (students). The results showed that the validity test by material experts and media experts was in the very valid category, namely $\geq 3.25$. The results of the practicality test are in the very practical category with the total percentage of each aspect $\geq 82 \%$.
\end{abstract}

Keywords: Interactive Learning Media, Powerpoint-Geogebra, Flat-sided Building Materials

\begin{abstract}
Abstrak
Penelitian ini bertujuan untuk menghasilkan media pembelajaran interaktif menggunakan powerpointgeogebra materi bangun ruang sisi datar yang valid dan praktis. Model penelitian yang digunakan dalam penelitian ini yaitu model ADDIE. Model pengembangan ADDIE terdiri dari lima tahap yaitu Analyze, Design, Development, Implement, dan Evaluation. Teknik pengumpulan data pada penelitian ini menggunakan lembar validasi dan angket respon peserta didik. Validitas produk dinilai berdasarkan hasil validasi ahli materi dan ahli media. Praktikalitas produk dinilai berdasarkan hasil uji coba kelompok kecil pada 6 peserta didik kelas VIII SMP Negeri 1 Reteh Pulau Kijang. Instrumen yang digunakan dalam penelitian ini adalah lembar validasi ahli media dan ahli materi serta angket respon peserta didik. Metode yang digunakan dalam pengumpulan data adalah dengan melakukan observasi dan wawancara. Teknik analisis data pada penelitian ini terdiri dari analisis lembar validasi oleh ahli dan audience (peserta didik). Hasil penelitian menunjukkan bahwa uji kevalidan oleh ahli materi dan ahli media dalam kategori sangat valid yaitu $\geq 3,25$. Hasil uji kepraktisan dalam kategori sangat praktis dengan presentase total setiap aspek $\geq 82 \%$.
\end{abstract}

Kata kunci: Media pembelajaran interaktif, Powerpoint-Geogebra, materi bangun ruang sisi datar

Copyright (c) 2022 Dewi Muliyana, Yenita Roza, Armis

$\triangle$ Corresponding author: Dewi Muliyana

Email Address: dewi.mulyana2572@student.unri.ac.id (Jalan Bangau Sakti, Pekanbaru)

Received 23 September 2021, Accepted 28 December 2021, Published 25 January 2022

\section{PENDAHULUAN}

Matematika merupakan salah satu mata pelajaran yang berkaitan dengan kehidupan seharihari. Matematika juga merupakan bidang studi yang harus dikuasai peserta didik, karena dapat membekali peserta didik dengan kemampuan berfikir logis, kritis, analisis, kreatif, dan mampu bekerja sama(Permendikbud, 2018). Geometri ruang merupakan salah satu materi matematika yang sulit untuk dipahami karena peserta didik sulit membayangkan bentuk-bentuk benda pada bangun ruang(Nurjanah \& Juliana, 2020). Sesuai dengan hasil UNBK Matematika SMP 2019 dari empat materi yang diujikan, materi geometri merupakan salah satu materi yang rendah persentasenya siswa 
menjawab benar yaitu hanya $42,27 \%$ dibandingkan dengan materi aljabar 51,24\% serta statistika dan peluang $55,60 \%$.

Geometri penting untuk dipelajari. Usiskin dalam (Darmawan, 2014)mengungkapkan alasan geometri perlu untuk dipelajari, yaitu (1) Geometri membantu manusia memiliki apresiasi yang utuh tentang dunianya. (2) Eksplorasi geometri dapat membantu mengembangkan keterampilan pemecahan masalah. (3) Geometri memainkan peranan utama dalam bidang matematika yang lainnya. (4) Geometri digunakan banyak orang dalam kehidupan sehari-hari. (5) Geometri penuh dengan tantangan dan menarik untuk diselesaikan. Oleh karena itu, bangun ruang sisi datar juga penting dipelajari oleh peserta didik karena merupakan bagian dari geometri ruang.

Bangun ruang sisi datar berkaitan dengan bentuk, posisi, ukuran, dan sifat suatu bangun sehingga dalam pembelajaran bangun ruang sisi datar dibutuhkan visualisasi yang tinggi. Bangun ruang sisi datar digunakan dalam kehidupan sehari-hari sehingga hal tersebut menuntut peserta didik untuk memahami konsep-konsep bangun ruang sisi datar(Zulhamma, 2020). Fakta di lapangan menurut (Hasibuan, 2018) memperlihatkan hal yang berbeda. Peserta didik masih banyak yang kesulitan menyelesaikan soal bangun ruang sisi datar. Kesulitan yang dihadapi adalah peserta didik tidak memahami secara benar bagaimana menentukan luas permukaan dan volume kubus, balok, prisma dan limas.

Pembelajaran materi bangun ruang sisi datar sebaiknya dilakukan menggunakan media pembelajaran agar peserta didik tidak sulit membayangkan bentuk- bentuk benda dari bangun ruang sisi datar. Panca indra tidak akan menangkap adanya titik, garis, rusuk, diagonal bidang, diagonal ruang, bidang diagonal dan sebagainya jika tidak menggunakan media(Sari et al., 2017). Pemanfaatkan media dalam proses pembelajaran dikelas yang sesuai dapat membantu peserta didik dalam mengungkapkan konsep-konsep matematika yang bersifat abstrak menjadi sebuah konsep yang nyata sehingga peserta didik dapat termotivasi menumbuhkan semangat minat belajar (Saputra \& Permata, 2018).

Saat peneliti melakukan observasi dan wawancara di SMP Negeri 1 Reteh peneliti menemukan bahwa saat siswa mempelajari materi bangun ruang sisi datar guru menggunakan media pembelajaran berupa model bangun ruang. Model bangun ruang tersebut tidak dapat menampilkan jaring-jaring bangun ruang sisi datar sehingga untuk menjelaskan materi unsur-unsur, sifat-sifat, luas permukaan dan volume bangun ruang sisi datar membutuhkan waktu untuk guru menggambar bangun ruang sisi datar di papan tulis. Selain membutuhkan waktu yang banyak dalam penjelasan materi, media tidak dapat digunakan untuk belajar mandiri oleh peserta didik.

Perkembangan ilmu pengetahuan dan teknologi memberikan dampak untuk diciptakannya suatu media pembelajaran yaitu media pembelajaran interaktif. Media pembelajaran interaktif dapat dipakai sebagai alat bantu dalam proses pembelajaran dimana guru menyampaikan pesan atau informasi kepada peserta didik (Jalinus \& Alim, 2018). Media Interaktif ini dapat berupa aplikasi komputer yang didesain sedemikian rupa sehingga dapat membuat terjadinya proses pembelajaran 
Pengembangan Media Pembelajaran Interaktif Menggunakan Powerpoint-Geogebra Materi Bangun Ruang Sisi Datar Kelas VIII SMP/MTs, Dewi Muliyana, Yenita Roza, Armis

dikelas. Namun, pemanfaatan media pembelajaran matematika berbasis komputer dalam proses pembelajaran saat ini belum banyak dipraktekkan. Hal ini sesuai dengan data BPS(Sutarsih \& Hasyyati, 2018) survey penggunaan dan pemanfaatan Teknologi Informasi dan Komunikasi di sektor pendidikan pada 34 provinsi, jenjang SMP hanya $19.22 \%$.

Penyajian materi bangun ruang sisi datar dapat dibuat menarik dengan media pembelajaran berbasis komputer karena bentuk-bentuk geometri bisa dibuat animasi. Sehingga peneliti mengembangkan suatu media pembelajaran interaktif yang dapat memvisualisasikan materi pembelajaran dengan lebih cepat, tepat dan memungkinkan setiap orang dimana pun dan kapan pun untuk belajar serta dapat digunakan untuk belajar sendiri maupun bersama-sama.

Salah satu Software yang dapat digunakan untuk membuat media pembelajaran interaktif adalah Microsoft PowerPoint yang diintegrasikan dengan Geogebra. (Emiliana Yolanda Primaningtyas, 2012) menunjukkan penggunaan media pembelajaran dengan program Microsoft PowerPoint dapat mempermudah tugas guru dalam menyajikan materi, mempersingkat durasi waktu yang dibutuhkan dan dapat menciptakan suasana belajar yang lebih interaktif.

Geogebra dapat membuat bangun dan animasi jaring-jaring bangun ruang sisi datar yang akan ditampilkan pada Microsoft PowerPoint. (Jannah \& Ika Faiqotul, 2020) menunjukkan bahwa Geogebra juga dapat digunakan untuk meningkatkan minat siswa dalam mengenal matematika dengan cara bereksperimen seperti dapat mengubah posisi dari bangun ruang dan mengetahui setiap unsur-unsur bangun ruang sisi datar. Peneliti menggunakan Geogebra untuk menjelaskan unsur-unsur dan sifat-sifat bangun ruang sisi datar karena dapat ditampilkan dengan jelas dan pengguna dapat mengubah posisi bangun secara tiga dimensi dari bangun ruang. Berdasarkan uraian permasalahan diatas, melalui penelitian ini dikembangkan media pembelajaran interaktif menggunakan powerpointgeogebra materi bangun ruang sisi datar kelas VIII SMP/MTs yang valid dan dilengkapi dengan buku panduan.

\section{METODE}

Penelitian ini merupakan penelitian pengembangan (R\&D) untuk menghasilkan media pembelajaran interaktif menggunakan Powerpoint-Geogebra materi bangun ruang sisi datar kelas VIII SMP/MTs yang dilengkapi dengan buku panduan. Model Pengembangan yang digunakan adalah model ADDIE (Analyze, Design, Development, Implement, Evaluation). Pembuatan produk dengan menggunakan ADDIE merupakan sebuah kegiatan yang menggunakan perangkat yang efektif (Robert Maribe Branch, 2009).

Pada tahap Analyze kegiatan yang dilakukan adalah melakukan analisis melalui observasi dan wawancara dengan guru matematika kelas VIII. Analisis yang dilakukan terdiri dari analisis situasi, analisis kebutuhan guru, analisis kebutuhan peserta didik, serta analisis kompetensi dasar dan materi bangun ruang sisi datar. Analisis situasi dilakukan untuk mengetahui dan mengklasifikasi permasalahan yang dihadapi guru berkaitan dengan media pembelajaran yang digunakan guru selama 
ini, kemudian menemukan solusi dengan mengembangkan media pembelajaran. Analisis kebutuhan yaitu menentukan media pembelajaran yang diperlukan oleh peserta didik untuk meningkatkan kualitas pembelajaran dan prestasi belajar peserta didik. Analisis kebutuhan guru dan analisis kebutuhan peserta didik digunakan untuk menemukan masalah yang ada dalam pembelajaran matematika kelas VIII. Analisis Kompetensi Dasar (KD) digunakan untuk mengembangkan indikator yang akan dimuat dalam media ini.

Pada tahap Design kegiatan awal yang dilakukan adalah merancang flowchart. Tujuan dari merancang flowchart yaitu untuk menunjukkan alur program dari media pembelajaran interaktif yang dikembangkan. Langkah selanjutnya yang dilakukan adalah pengumpulan bahan (materi ajar, background, backsound, gambar dan animasi). Bahan-bahan yang dikumpulkan berupa materi ajar materi bangun ruang sisi datar yang diperoleh melalui berbagai sumber yang dianggap relevan dan sesuai dengan materi bangun ruang sisi datar dalam pengembangan media pembelajaran. Sound dalam media pembelajaran interaktif ini berasal dari peneliti sendiri. Langkah ketiga yang dilakukan yaitu merancang tampilan dan petunjuk penggunaan media pembelajaran dan langkah terakhir yang dilakukan pada penelitian ini adalah mendesain instrumen penilaian kelayakan media berupa lembar validasi ahli dan lembar angket respon peserta didik.

Pada tahap Development kegiatan yang dilakukan adalah mengembangkan media pembelajaran interaktif sesuai dengan rancangan yang telah disusun. Rancangan tampilan media pembelajaran yang telah dirancang kemudian dibuat dalam software Microsoft Powerpoint yang diintegrasikan dengan Geogebra. Rancangan petunjuk penggunaan dikemas dalam bentuk buku. Media yang telah dibuat dengan software Microsoft Powerpoint yang diintegrasikan dengan Geogebra dikemas dalam link Google Drive dan Barkode Scanner yang dapat dibuka melalui laptop atau komputer. Media dan petunjuk penggunaan yang telah dikemas kemudian dikonsultasikan kepada dosen pembimbing. Tujuan dari pengecekan oleh dosen adalah untuk dilakukan pengecekan dan memberikan masukan atau saran terhadap media pembelajaran interaktif yang telah dibuat. Setelah dilakukan pengecekan oleh dosen, media pembelajaran siap untuk divalidasi oleh ahli (Validator) hingga dinyatakan valid. Jika media pembelajaran interaktif memperoleh katogeri tidak valid berdasarkan validasi oleh ahli, maka dilakukan revisi pada media pembelajaran terlebih dahulu. Media pembelajaran dengan kategori valid oleh ahli siap dilakukan uji kepraktisan oleh peserta didik.

Pada tahap Implementation kegiatan yang dilakukan adalah melakukan uji coba kelompok kecil terhadap media pembelajaran interaktif menggunakan Powerpoint-Geogebra melalui angket respon peserta didik untuk mengetahui kepraktisan terhadap penggunaan media pembelajaran interaktif. Uji coba kelompok kecil dilakukan kepada 6 orang peserta didik kelas VIII SMP Negeri 1 Reteh. Pada penelitian ini, uji coba yang dilakukan hanya uji coba kelompok kecil. Peneliti tidak melakukan uji coba kelompok besar karena kondisi yang tidak memungkinkan untuk dilakukan uji coba kelompok besar. 
Pengembangan Media Pembelajaran Interaktif Menggunakan Powerpoint-Geogebra Materi Bangun Ruang Sisi Datar Kelas VIII SMP/MTs, Dewi Muliyana, Yenita Roza, Armis

Pada tahap Evaluation kegiatan yang dilakukan adalah melakukan analisis terhadap angket respon peserta didik untuk menilai dan mengevaluasi media pembelajaran interaktif. Jika media pembelajaran interaktif menggunakan Powerpoint-Geogebra materi bangun ruang sisi datar yang telah diuji coba memperoleh hasil yang praktis, maka media pembelajaran tersebut akan dikemas dalam link Google Drive dan Barkode Scanner

Data penelitian ini terdiri dari dua yaitu data kualitatif dan data kuantitatif. Data kualitatif diperoleh dari saran yang berasal dari validator serta peserta didik terhadap media pembelajaran interaktif materi bangun ruang sisi datar kelas VIII SMP/MTs menggunakan Powerpoint-Geogebra. Data kuantitatif diperoleh dari lembar validasi dan angket respon peserta didik yang diberikan kepada validator dan peserta didik untuk menilai media pembelajaran interaktif materi bangun ruang sisi datar kelas VIII SMP/MTs menggunakan Powerpoint-Geogebra. Uji validitas pada media pembelajaran interaktif ini terdiri dari dua yaitu validitas oleh ahli materi dan ahli media yang dilakukan oleh tiga orang ahli. Uji kepraktisan pada media pembelajaran interaktif ini menggunakan angket respon peserta didik yang dilakukan oleh enam orang peserta didik SMP Negeri 1 Reteh. Teknik analisis data pada penelitian ini terdiri dari analisis lembar validasi media pembelajaran interaktif menggunakan powerpoint-geogebra oleh ahli dan lembar angket respon peserta didik.

\section{HASIL DAN DISKUSI}

Produk yang dihasilkan pada penelitian ini adalah media pembelajaran interaktif menggunakan powerpoint-geogebra materi bangun ruang sisi datar kelas VIII SMP/MTs yang dilengkapi dengan buku panduan. Proses pengembangan media pembelajaran interaktif ini sampai dinyatakan valid dan praktis dilakukan melalui lima tahap yaitu analyze, design, development, implementation dan evaluation.

\section{Analyze}

Pada tahap Analyze peneliti melakukan analisis melalui observasi dan wawancara di SMP Negeri 1 Reteh. Analisis yang dilakukan terdiri dari analisis situasi, analisis kebutuhan guru, analisis kebutuhan peserta didik serta analisis kompetensi dasar dan materi bangun ruang sisi datar. Wawancara yang dilakukan dengan guru matematika kelas VIII SMP Negeri 1 Reteh diperoleh bahwa : (1) Pembelajaran dikelas menjadi aktif dan menyenangkan ketika guru menggunakan media pembelajaran seperti pada materi bangun ruang sisi datar. Guru menggunakan media berupa model bangun ruang sisi datar untuk menunjukkan bentuk dari bangun ruang sisi datar. (2) Penggunaan media pembelajaran interaktif menggunakan aplikasi komputer tidak pernah dilakukan dengan alasan pembuatannya sulit sehingga media yang digunakan berupa media sederhana. (3) Media yang digunakan guru pada pembelajaran tidak dapat digunakan peserta didik diluar pembelajaran karena media tersebut jumlahnya terbatas dan tidak dapat dibawa kemana-mana sehingga tidak dapat digunakan untuk belajar mandiri oleh peserta didik. 
Beberapa kendala yang dialami oleh guru matematika SMP Negeri 1 Reteh dengan media pembelajaran yang digunakannya adalah media pembelajaran tidak dapat dibuka sehingga guru kesulitan menampilkan jaring-jaring dan unsur-unsur bangun ruang sisi datar. Guru juga kesulitan menjelaskan cara menemukan rumus luas permukaan dan volume bangun ruang sisi datar. Guru memerlukan waktu yang banyak untuk menjelaskan materi bangun ruang sisi datar dengan media yang ada karena harus menggambarkan dipapan tulis lagi. Guru juga kesulitan untuk memberikan contoh - contoh soal bangun ruang sisi datar yang harus selalu dihubungkan dengan kehidupan seharihari.

Guru matematika SMP Negeri 1 Reteh menyatakan bahwa lebih dari 50\% peserta didik mengalami kesulitan dalam memecahkan masalah yang berhubungan dengan kehidupan sehari-hari. Peserta didik juga kesulitan menyelesaikan soal pemahaman dan hubungan unsur-unsur bangun ruang sisi datar. Misalnya, guru memberikan pertanyaan menentukan diagonal bidang kubus sedangkan pada soal hanya diketahui volume kubus. Peserta didik sering bingung dan salah untuk menyelesaikan soal tersebut. Kesalahan tersebut sering dilakukan karena kurangnya pemahaman peserta didik dalam memahami konsep bangun ruang sisi datar sementara jika dilakukan pengulangan materi akan mengurangi alokasi waktu yang seharusnya digunakan untuk mempelajari materi selanjutnya.

Berdasarkan hasil wawancara yang telah dilaksanakan, dibutuhkan media yang bersifat interaktif menggunakan aplikasi computer dan dapat digunakan untuk belajar mandiri oleh peserta didik dan dapat mengatasi kesulitan guru untuk menjelaskan materi jaring-jaring, unsur-unsur serta menemukan rumus luas permukaan dan volume bangun ruang sisi datar sehinggga peneliti mengembangkan media pembelajaran bersifat interaktif dengan bantuan aplikasi komputer serta dapat digunakan oleh guru dan siswa baik dalam pembelajaran maupun diluar pembelajaran.

Pada analisis kompetensi dasar dan materi, peneliti mengacu pada Kurikulum 2013 kelas VIII SMP/MTs yang tercantum dalam Permendikbud Nomor 37 Tahun 2018 sehingga dapat membagi materi pembelajaran mengenai pengertian kubus, unsur-unsur dan sifat-sifat kubus, luas permukaan kubus, volume kubus, pengertian balok, unsur-unsur dan sifat-sifat balok, luas permukaan balok, volume balok, pengertian prisma, unsur-unsur dan sifat-sifat prisma, jenis-jenis prisma, luas permukaan prisma, volume prisma, pengertian limas, unsur-unsur dan sifat-sifat limas, jenis-jenis limas, luas permukaan limas, dan volume limas.

\section{Design}

Tahap design (perancangan), peneliti membuat rancangan flowchart, merancang tampilan dan petunjuk penggunaan media pembelajaran interaktif menggunakan powerpoint-geogebra, dan membuat lembar validasi media pembelajaran interaktif. Tahap perancangan diawali dengan membuat rancangan flowchart untuk memudahkan perancangan tampilan media pembelajaran interaktif. Setelah merancang flowchart selanjutnya peneliti mengumpulkan bahan yang diperlukan untuk membuat media pembelajaran interaktif yang terdiri dari gambar, animasi, background dan sound dari peneliti. 
Pengembangan Media Pembelajaran Interaktif Menggunakan Powerpoint-Geogebra Materi Bangun Ruang Sisi Datar Kelas VIII SMP/MTs, Dewi Muliyana, Yenita Roza, Armis

Langkah selanjutnya yang dilakukan adalah peneliti merancang tampilan media pembelajaran untuk memudahkan pembuatan media pembelajaran interaktif. Perancangan tampilan media pembelajaran dibuat dengan menggunakan Microsoft Word. Berikut adalah contoh hasil rancangan tampilan halaman home dan halaman fungsi tombol yang akan dikompilasi pada Microsoft Powerpoint serta rancangan tampilan halaman materi unsur-unsur dan sifat-sifat bangun ruang sisi datar yang akan dikompilasi pada Geogebra.

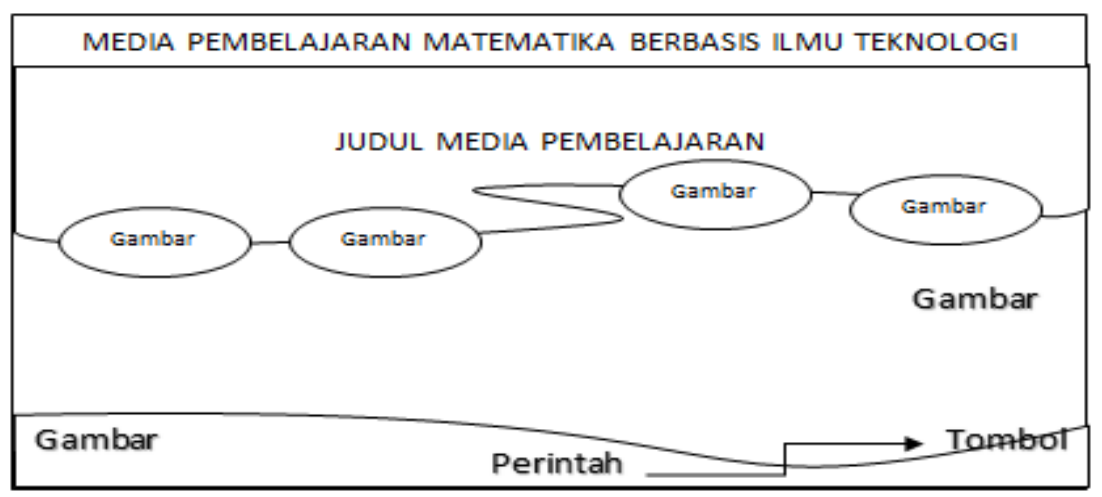

Gambar 1. Rancangan Tampilan Halaman Home

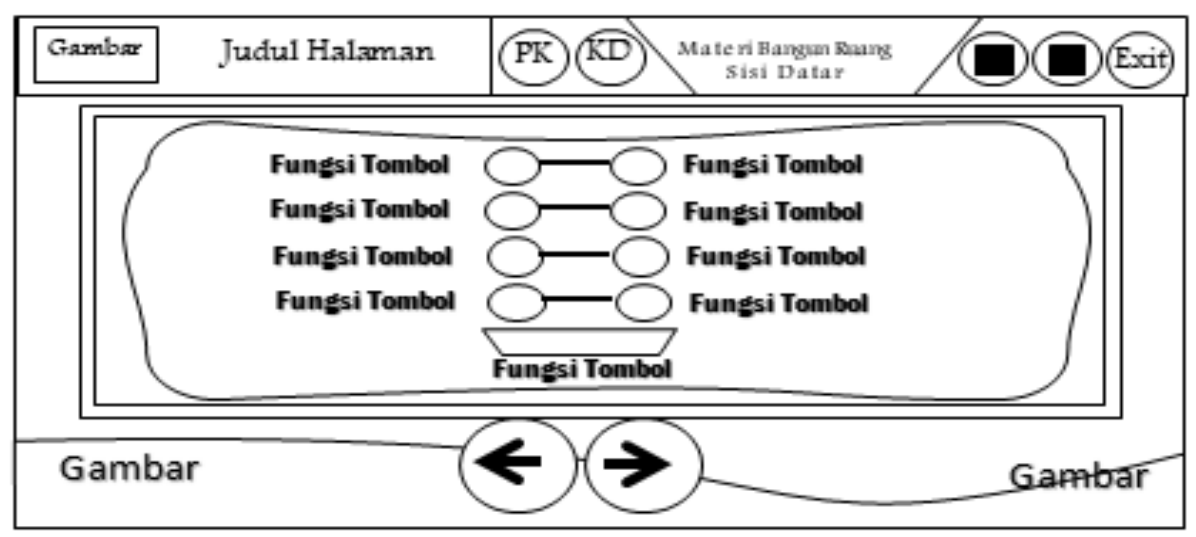

Gambar 2. Rancangan tampilan halaman fungsi tombol.

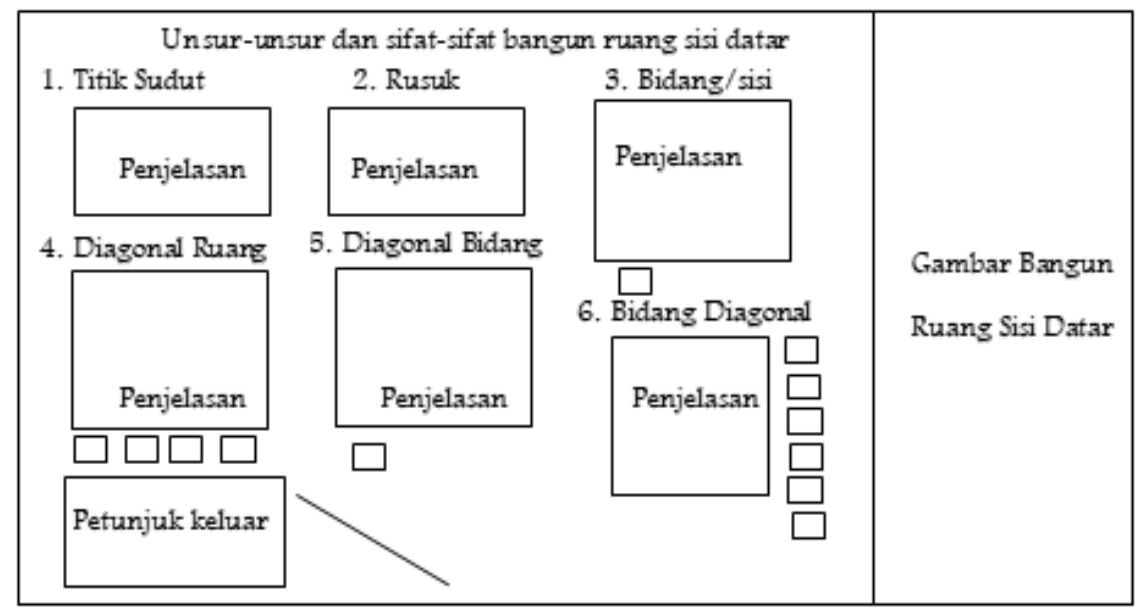

Gambar 3. Rancangan tampilan materi unsur-unsur dan sifat-sifat bangun ruang sisi datar 
Setelah rancangan tampilan media pembelajaran interaktif selesai dibuat pada Microsoft Word, selanjutnya peneliti membuat rancangan petunjuk penggunaan media. Petunjuk penggunaan media terdiri dari penggunaan media melalui whatsapp, email, link google drive, barcode scanner, dan panduan membuka materi pada media pembelajaran interaktif menggunakan PowerpointGeogebra.

\section{Development}

Pada tahap Development (Pengembangan), rancangan tampilan media pembelajaran interaktif kemudian dibuat dalam Microsoft Powerpoint yang diintegrasikan dengan Geogebra dan menggunakan bahan-bahan yang telah dikumpulkan berupa gambar, animasi, background dan sound dari peneliti. Pada tahap ini juga rancangan petunjuk penggunaan yang dibuat pada Microsoft word dikemas dalam bentuk buku panduan. Berikut adalah contoh hasil tampilan halaman home dan halaman fungsi tombol yang akan dikompilasi pada Microsoft Powerpoint serta tampilan halaman materi unsur-unsur dan sifat-sifat bangun ruang sisi datar yang akan dikompilasi pada Geogebra.

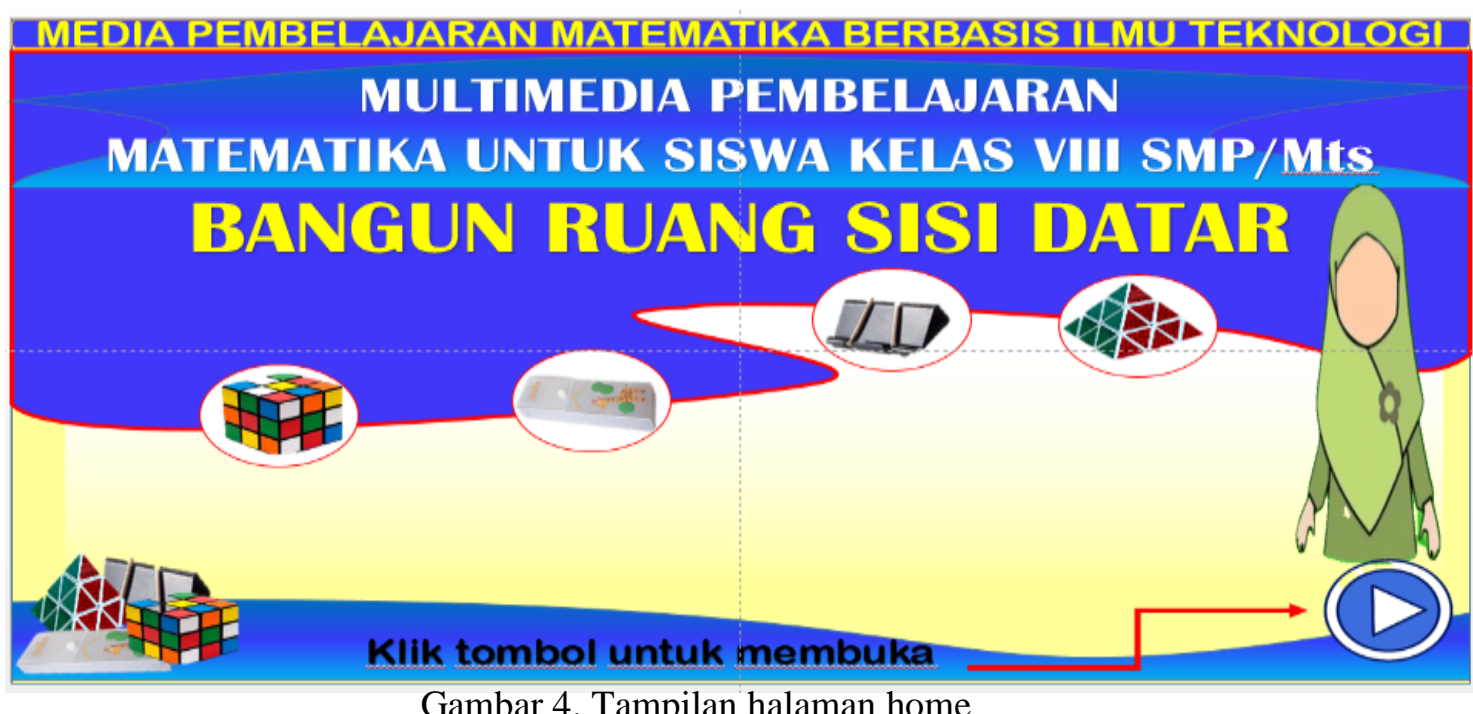

Gambar 4. Tampilan halaman home

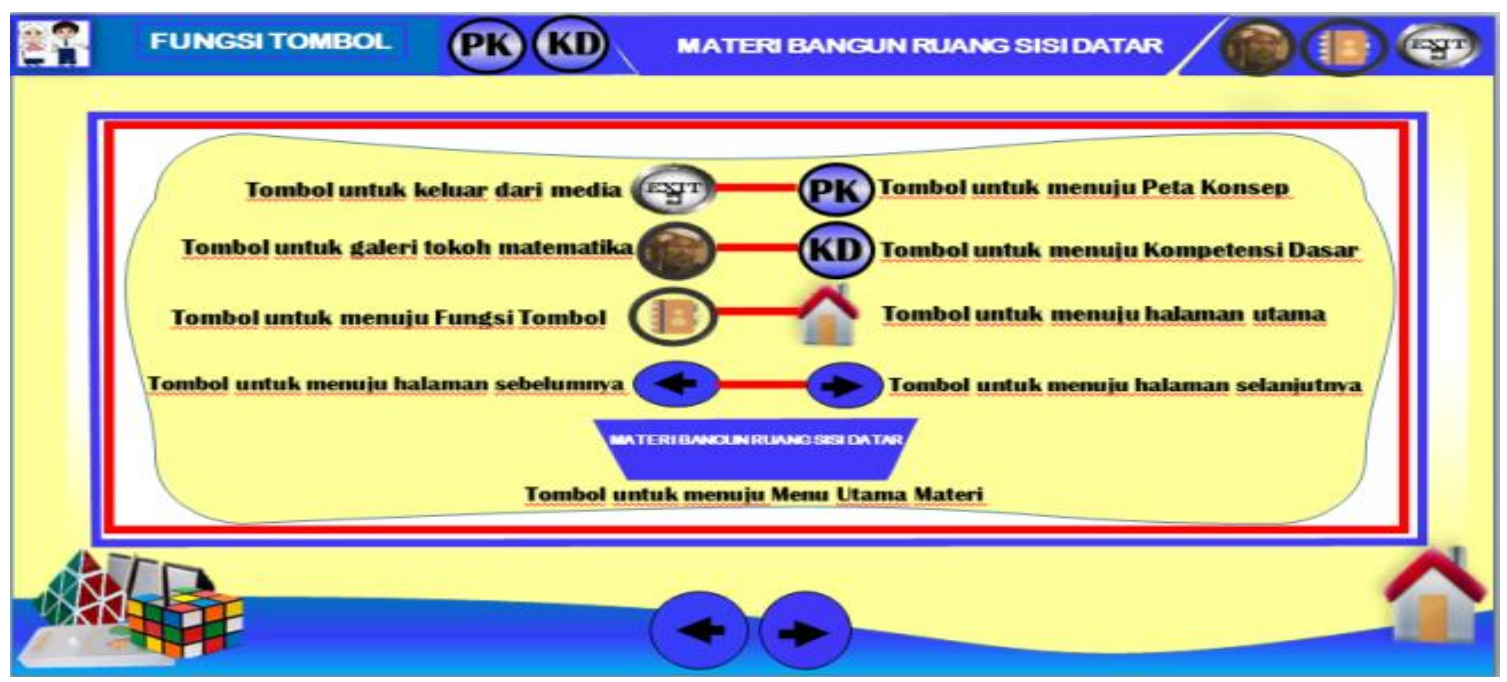

Gambar 5. Tampilan Halaman Petunjuk Penggunaan 
Pengembangan Media Pembelajaran Interaktif Menggunakan Powerpoint-Geogebra Materi Bangun Ruang Sisi Datar Kelas VIII SMP/MTs, Dewi Muliyana, Yenita Roza, Armis

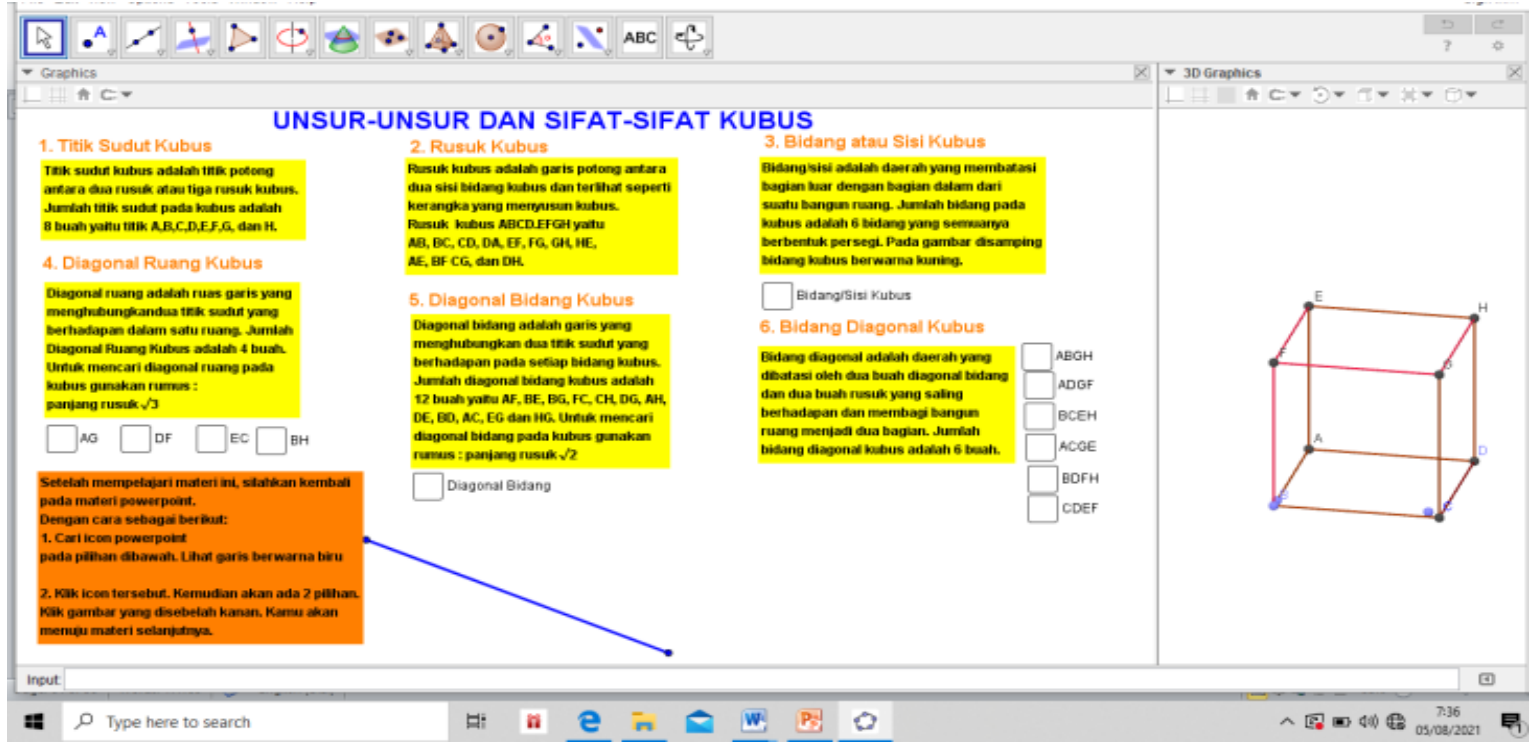

Gambar 6. Tampilan Materi Unsur-Unsur dan Sifat-Sifat Bangun Ruang Sisi Datar

Media pembelajaran interaktif menggunakan Powerpoint-Geogebra yang telah dikembangkan selanjutnya divalidasi oleh tiga orang ahli materi dan ahli media serta enam orang peserta didik. Hasil dari validasi oleh tiga orang ahli dapat dilihat pada Tabel 3 berikut.

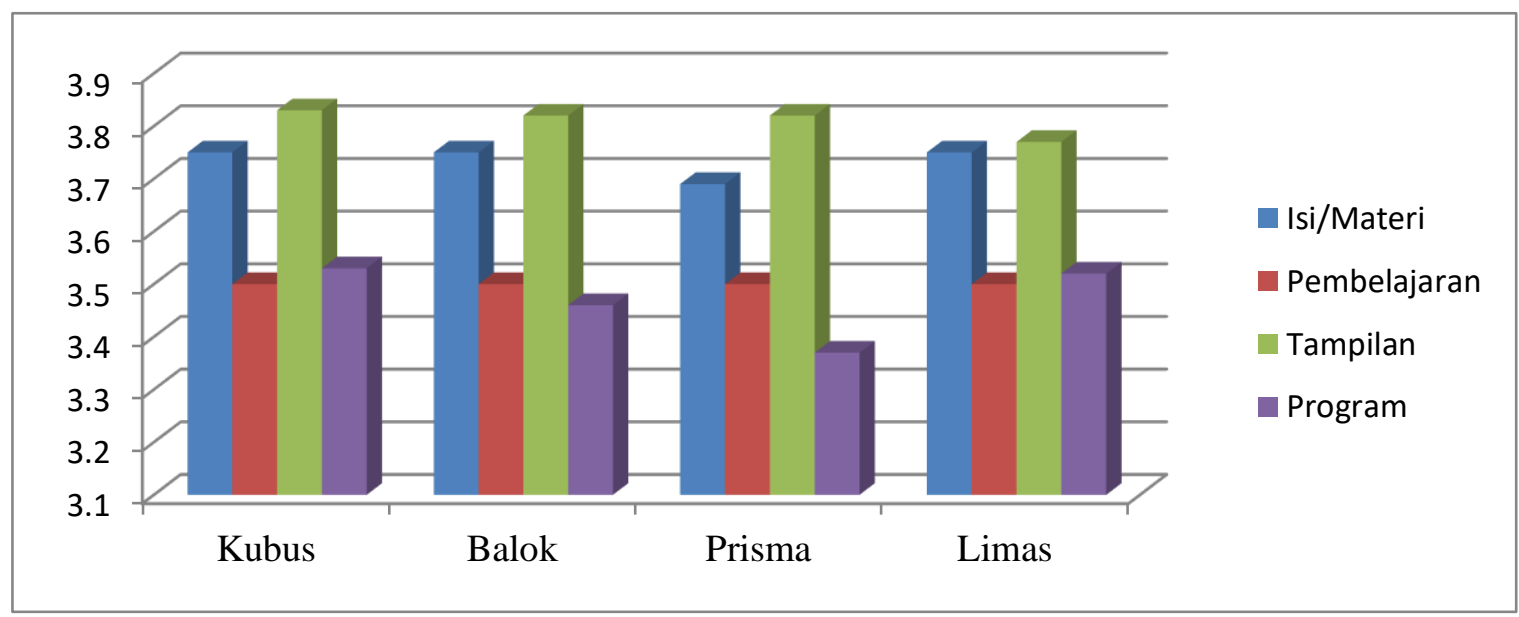

Gambar 7. Hasil uji validasi oleh ahli materi dan ahli media

Grafik pada Gambar 7 menunjukkan bahwa media pembelajaran interaktif menggunakan powerpoint-geogebra materi bangun ruang sisi datar kelas VIII SMP/MTs dari aspek tampilan, aspek program, aspek isi/materi dan aspek pembelajaran secara keseluruhan dapat disimpulkan bahwa media pembelajaran ini sangat valid, dengan penilaian setiap aspek dari sub materi kubus, balok, prisma dan limas memiliki aspek $\geq 3,25$. Namun, disamping itu terdapat beberapa saran dari validator ahli yang dijelaskan pada Tabel 1 . 
Tabel 1. Saran dan Hasil Perbaikan dari Validasi oleh Ahli

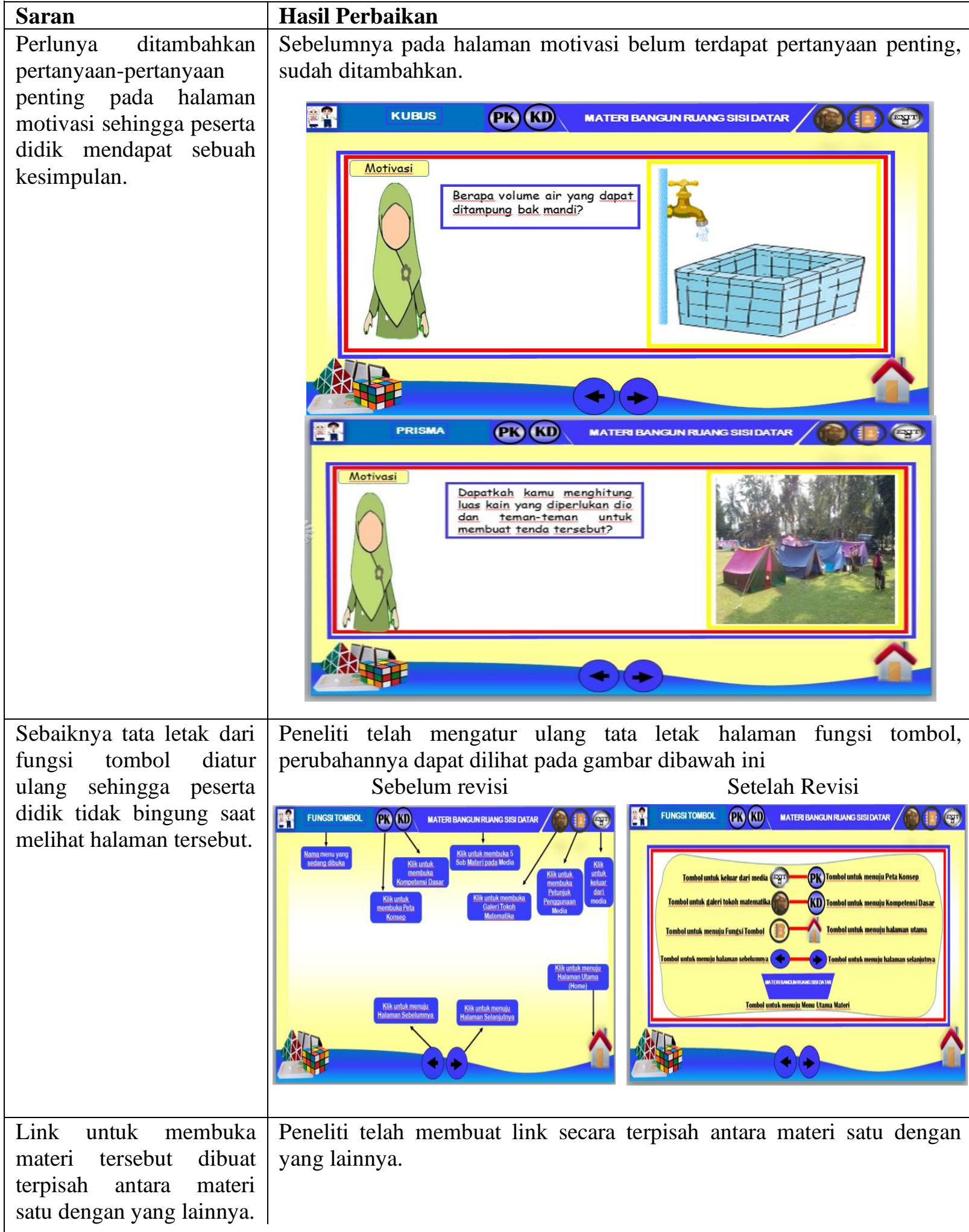

Setelah dilakukan validasi oleh ahli dan perbaikan pada produk media pembelajaran interaktif selanjutnya dilakukan uji kepraktisan yang melibatkan enam orang peserta didik SMP Negeri 1 Reteh. 
Pengembangan Media Pembelajaran Interaktif Menggunakan Powerpoint-Geogebra Materi Bangun Ruang Sisi Datar Kelas VIII SMP/MTs, Dewi Muliyana, Yenita Roza, Armis

\section{Implementation dan Evaluation}

Pada tahap Implentation (Implementasi), produk dengan kategori sangat valid berdasarkan hasil validasi oleh ahli selanjutnya dilakukan uji kepraktisan oleh peserta didik kelas VIII SMP Negeri 1 Reteh. Siswa dipilih dengan kemampuan yang Heterogen. Pada uji coba kelompok kecil peserta didik diminta menggunakan media pembelajaran interaktif dan mengerjakan latihan yang terdapat pada media pembelajaran. Adapun hasil uji praktikalitas media pembelajaran interaktif menggunakan Powerpoint-Geogebra dapat dilihat pada Tabel 2 berikut.

Tabel 2. Hasil Validasi Oleh Audience (Peserta Didik)

\begin{tabular}{|l|l|l|l|}
\hline \multirow{2}{*}{ Sub Materi } & \multicolumn{3}{c|}{ Persentase Tiap Aspek } \\
\cline { 2 - 4 } & Isi dan Tujuan & Pembelajaran & Kualitas Teknis \\
\hline Kubus & $90,28 \%$ & $91,67 \%$ & $94,67 \%$ \\
\hline Balok & $90,28 \%$ & $90,63 \%$ & $94,17 \%$ \\
\hline Prisma & $88,89 \%$ & $86,46 \%$ & $92,92 \%$ \\
\hline Limas & $89,58 \%$ & $85,42 \%$ & $92,92 \%$ \\
\hline Persentase Total & $89,76 \%$ & $88,55 \%$ & $93,67 \%$ \\
\hline
\end{tabular}

Tabel 2 menunjukkan bahwa media pembelajaran interaktif menggunakan powerpointgeogebra materi bangun ruang sisi datar kelas VIII SMP/MTs dari aspek isi dan tujuan, aspek pembelajaran dan aspek kulitas teknis secara keseluruhan dapat disimpulkan bahwa media pembelajaran ini sangat valid ditandai dengan presentase total setiap aspek $\geq 85 \%$ dan komentarkomentar positif dari peserta didik. Peserta didik menggunakan media pembelajaran ini dirumah. Peneliti membuat grup whatsapp terlebih dahulu untuk mengumpulkan peserta didik yang akan menggunakan media pembelajaran ini. Kemudian peneliti mengirim media pembelajaran interaktif dan link angket repon dari setiap materi ke grup tersebut. Setelah peserta didik memberikan respon terhadap media pembelajaran interaktif melalui angket, peneliti dan peserta didik melakukan diskusi melalui aplikasi zoom meeting untuk mengetahui respon penggunaan media pembelajaran interaktif.

Diskusi yang telah dilakukan peneliti dengan peserta didik, diperoleh bahwa peserta didik sangat tertarik dengan media pembelajaran yang mereka jalankan. Peserta didik mengatakan dengan menggunakan media pembelajaran ini, mereka dapat melihat setiap bangun ruang sisi datar secara 3 dimensi dan mereka juga saling berdiskusi untuk menemukan jawaban dari soal-soal pada media pembelajaran.

\section{KESIMPULAN}

Berdasarkan hasil penelitian pengembangan yang dilakukan oleh peneliti dapat disimpulkan bahwa media pembelajaran interaktif menggunakan powerpoint-geogebra materi bangun ruang sisi datar kelas VIII SMP/MTs media pembelajaran interaktif menggunakan powerpoint-geogebra materi bangun ruang sisi datar kelas VIII SMP/MTs telah dinilai sangat valid dari validator dengan penilaian setiap aspek dari sub materi kubus, balok, prisma dan limas memiliki aspek $\geq 3,25$ dan dari peserta 
didik dengan presentase total setiap aspek $\geq 85 \%$. Peneliti menyarankan agar pengembangan media pembelajaran interaktif selanjutnya mampu sampai pada tahap uji coba kelompok kecil dan uji coba kelompok besar dan tahap melihat pengaruh penggunaan media pembelajaran interaktif pada hasil belajar peserta didik.

\section{UCAPAN TERIMA KASIH}

Peneliti mengucapkan terima kasih kepada Allah SWT yang telah memberikan kemudahan dan kelancaran dalam pelaksanaan penelitian ini. Peneliti mengucapkan terima kasih kepada kedua orang tua, keluarga dan teman-teman yang selalu memberikan doa, dorongan dan semangat. Peneliti juga mengucapkan terima kasih kepada ibu Dra. Yenita Roza, Ph. D dan ibu Dra. Armis, M.Pd selaku dosen pembimbing yang selalu memberikan arahan dan bimbingan selama penelitian dan penulisan artikel ini. Dan peneliti mengucapkan terima kasih kepada Project AKSI ADB UNRI yang menyediakan dana melalui Program Riset Penelitian Mahasiswa Tahun Anggaran 2021.

\section{REFERENSI}

Darmawan, D. (2014). Peningkatan Kemampuan Pemecahan Masalah Geometri melalui Pembelajaran Kooperatif Berbasis Teori Van Hiele. Jurnal Didaktik Matematika, 1(1). https://doi.org/10.24815/jdm.v1i1.1238

Hasibuan, E. K. (2018). ANALISIS KESULITAN BELAJAR MATEMATIKA SISWA PADA POKOK BAHASAN BANGUN RUANG SISI DATAR DI SMP NEGERI 12 BANDUNG. AXIOM : Jurnal Pendidikan Dan Matematika, 7(1). https://doi.org/10.30821/axiom.v7i1.1766

Jalinus, J., \& Alim, J. A. (2018). PENGEMBANGAN MEDIA PEMBELAJARAN MATEMATIKA INTERAKTIF BERBASIS KOMPUTER PADA TOPIK BILANGAN BULAT UNTUK SISWA SD PENDIDIKAN MATEMATIKA FKIP UNRI. Tunjuk Ajar: Jurnal Penelitian Ilmu Pendidikan. https://doi.org/10.31258/jta.v1i1.14-26

Nurjanah, \& Juliana, A. (2020). Hambatan Didaktis Siswa SMP dalam Penyelesaian Masalah Geometri Berdasarkan Kemampuan Persepsi Ruang. Kreano, Jurnal Matematika KreatifInovatif, 11(2).

Permendikbud. (2018). Peraturan Menteri Pendidikan Dan Kebudayaan Republik Indonesia Nomor 58 Tahun 2014. Sereal Untuk, 51(1).

Saputra, V. H., \& Permata, P. (2018). Media Pembelajaran Interaktif Menggunakan Macromedia Flash Pada Materi Bangun Ruang. WACANA AKADEMIKA: Majalah Ilmiah Kependidikan. https://doi.org/10.30738/wa.v2i2.3184

Sari, A. U., Farida, F., \& Putra, F. G. (2017). Pengembangan Media Pembelajaran Berbantuan Web Dengan Pendekatan Etnomatematika Pada Pokok Bahasan Bangun Ruang Sisi Datar. In Prosiding Seminar Nasional Matematika dan Pendidikan Matematika (Vol. 1, Issue 1). 
Pengembangan Media Pembelajaran Interaktif Menggunakan Powerpoint-Geogebra Materi Bangun Ruang Sisi Datar Kelas VIII SMP/MTs, Dewi Muliyana, Yenita Roza, Armis

Sugiono. 2015. Metode penelitian dan pengembangan (Research and Development/R\&D). Bandung : Alfabeta

Sutarsih, T., \& Hasyyati, A. (2018). Penggunaan dan Pemanfaatan Teknologi Informasi dan Komunikasi (P2TIK) Sektor Pendidikan 2018. In BPS Republik Indonesia.Darmawan, D. (2014). Peningkatan Kemampuan Pemecahan Masalah Geometri melalui Pembelajaran Kooperatif Berbasis Teori Van Hiele. Jurnal Didaktik Matematika, l(1). https://doi.org/10.24815/jdm.v1i1.1238

Zulhamma, R. (2020). ANALISIS KEMAMPUAN SISWA DALAM MENYELESAIKAN SOAL BANGUN RUANG SISI DATAR. Jurnal LEMMA, 6(2). https://doi.org/10.22202/j1.2020.v6i2.3379 